\title{
Plant and Microbial Controls on Nitrogen Retention and Loss in a Humid Tropical Forest
}

\author{
Pamela H. Templer ${ }^{1,2^{*}}$, Whendee L. Silver ${ }^{1}$, Jennifer Pett-Ridge ${ }^{1,3}$, Kristen DeAngelis ${ }^{1,4}$ \\ and Mary K. Firestone ${ }^{1}$
}

1. Ecosystem Sciences Division, Department of Environmental Science, Policy, and Management, University of California, Berkeley, CA 94720.

2. Current address: Department of Biology, Boston University, 5 Cummington Street, Boston, MA 02215. URL: people.bu.edu/ptempler

3. Current address: Chemical Biology and Nuclear Science Division, Lawrence Livermore National Lab, P.O. Box 808, L-231, Livermore CA, 94551-9900

4. Current address: Earth Sciences Division, Lawrence Berkeley National Lab, 1 Cyclotron Road, Berkeley, CA 94720

*Corresponding author: Dr. Pamela Templer, current address: Department of Biology, Boston University, 5 Cummington Street, Boston, MA 02215. Email: ptempler@bu.edu. Fax: 617-3536340. 


\begin{abstract}
Humid tropical forests are generally characterized by the lack of nitrogen $(\mathrm{N})$ limitation to net primary productivity, yet paradoxically have high potential for $\mathrm{N}$ loss. We conducted an intensive field experiment with ${ }^{15} \mathrm{NH}_{4}$ and ${ }^{15} \mathrm{NO}_{3}$ additions to highly weathered tropical forest soils to determine the relative importance of $\mathrm{N}$ retention and loss mechanisms. Over half of all the $\mathrm{NH}_{4}{ }^{+}$produced from gross mineralization was rapidly converted to $\mathrm{NO}_{3}{ }^{-}$during the process of gross nitrification. During the first $24 \mathrm{~h}$ plant roots took up $28 \%$ of the $\mathrm{N}$ mineralized, dominantly as $\mathrm{NH}_{4}{ }^{+}$, and were a greater sink for $\mathrm{N}$ than soil microbial biomass. Soil microbes were not a significant sink for added ${ }^{15} \mathrm{NH}_{4}{ }^{+}$or ${ }^{15} \mathrm{NO}_{3}{ }^{-}$during the first $24 \mathrm{hr}$, and only for ${ }^{15} \mathrm{NH}_{4}{ }^{+}$ after $7 \mathrm{~d}$. Patterns of microbial community composition, as determined by Terminal Restriction Fragment Length Polymorphism analysis, were weakly, but significantly correlated with nitrification and denitrification to $\mathrm{N}_{2} \mathrm{O}$. Rates of dissimilatory $\mathrm{NO}_{3}{ }^{-}$reduction to $\mathrm{NH}_{4}{ }^{+}$(DNRA) were high in this forest, accounting for up to $25 \%$ of gross mineralization and $35 \%$ of gross nitrification. DNRA was a major sink for $\mathrm{NO}_{3}{ }^{-}$which may have contributed to the lower rates of $\mathrm{N}_{2} \mathrm{O}$ and leaching losses. Despite considerable $\mathrm{N}$ conservation via DNRA and plant $\mathrm{NH}_{4}^{+}$ uptake, the fate of approximately $45 \%$ of the $\mathrm{NO}_{3}{ }^{-}$produced and $22 \%$ of the $\mathrm{NH}_{4}{ }^{+}$produced were not measured in our fluxes, suggesting that other important pathways for $\mathrm{N}$ retention and loss (e.g., denitrification to $\mathrm{N}_{2}$ ) are important in this system. The high proportion of mineralized $\mathrm{N}$ that was rapidly nitrified and the fates of that $\mathrm{NO}_{3}{ }^{-}$highlight the key role of gross nitrification as a proximate control on $\mathrm{N}$ retention and loss in humid tropical forest soils. Furthermore, our results demonstrate the importance of the coupling between DNRA and plant uptake of $\mathrm{NH}_{4}{ }^{+}$as a potential $\mathrm{N}$ conserving mechanism within tropical forests.
\end{abstract}


Keywords: plant-microbial uptake, nitrogen sinks, ${ }^{15} \mathrm{~N}$, gross mineralization and nitrification, DNRA, denitrification, nitrous oxide

\section{Introduction}

The internal transformations of nitrogen $(\mathrm{N})$ in terrestrial ecosystems exert strong controls on $\mathrm{N}$ availability, ultimately affecting net primary productivity (NPP; Mellilo et al. 1993, Stark and Hart 1997), $\mathrm{NO}_{3}{ }^{-}$leaching into groundwater (Vitousek and Matson 1984, Hedin et al. 1998), and emissions of N-based greenhouse gases (Firestone and Davidson 1989, Matson et al. 1999, Hall and Matson, 1999). In north temperate ecosystems N limitation to NPP is common (Vitousek and Howarth 1991). In contrast, the tropics are generally characterized by rapid rates of N cycling and the lack of strong N limitation to NPP (Vitousek and Sanford 1986). Indeed, $\mathrm{N}$ fertilization experiments conducted on highly weathered tropical forest soils, typical of large areas of the tropical biome, have demonstrated little evidence of N limitation to NPP (Tanner et al. 1992, Herbert and Fownes 1995, Vitousek and Farrington 1997). This occurs despite large potential N losses via denitrification (Livingston et al. 1988) and leaching (Lewis et al. 1999) from these ecosystems.

The apparent paradox of adequate $\mathrm{N}$ availability, despite a high potential for losses, can be explained by either high inputs (i.e., $\mathrm{N}$ fixation rates) or effective $\mathrm{N}$ retention. Recent studies suggest that ecosystem-level rates of $\mathrm{N}$ fixation can be high (Reed et al. 2007), but large amounts of $\mathrm{N}$ fixation are unlikely to be pervasive throughout mature tropical forests (Vitousek et al. 2002). There is some evidence in support of highly effective nutrient retention in these ecosystems (e.g., Davidson et al. 2007), but the mechanisms underlying such a response have not been thoroughly examined. Nitrogen can be retained in forest ecosystems via plant and microbial 
uptake and assimilation into biomass, storage as soil organic $\mathrm{N}$, or as inorganic $\mathrm{N}$ adsorbed onto soil exchange sites and soil organic matter. In temperate soils where $\mathrm{N}$ is often a limiting nutrient for plants, microbes out-compete plants for mineral $\mathrm{N}$ in the short term (e.g., $\leq 24 \mathrm{~h}$; Jackson et al. 1989; Zogg et al. 2000; Templer et al. 2005). In tropical soils, the relative fate of inorganic $\mathrm{N}$ in plants versus microbial biomass is not well known because most studies have only examined microbial uptake of $\mathrm{N}$ in the absence of plant roots. Those studies examining microbial uptake show that microbes take up more $\mathrm{NH}_{4}{ }^{+}$than $\mathrm{NO}_{3}{ }^{-}$(Vitousek and Matson 1988, Silver et al. 2001, 2005), possibly due to energetic constraints (Puri and Ashmann 1999). Ammonium uptake may be favored since this form of $\mathrm{N}$ does not need to be reduced prior to assimilation, unlike $\mathrm{NO}_{3}{ }^{-}$.

Nitrate is generally more easily leached than $\mathrm{NH}_{4}{ }^{+}$in soils and is an important substrate for denitrification to $\mathrm{N}_{2} \mathrm{O}, \mathrm{NO}$, and $\mathrm{N}_{2}$. Both leaching and denitrification are important $\mathrm{N}$ loss pathways in humid tropical forests (Lewis et al. 1999, Stehfest and Bouwman 2007), which are typically characterized by considerable hydrologic throughput (Schellekens et al. 2004) and fluctuating redox conditions which can stimulate denitrification (Silver et al. 1999, 2005). Nitrate can be rapidly converted to $\mathrm{NH}_{4}{ }^{+}$during dissimilatory $\mathrm{NO}_{3}{ }^{-}$reduction to $\mathrm{NH}_{4}{ }^{+}$(DNRA), a microbial process that occurs under low or fluctuating redox conditions similar to denitrification (Tiedje 1988; Silver et al. 2001). In tropical forests, DNRA could contribute to N retention by decreasing the size of the $\mathrm{NO}_{3}{ }^{-}$pool (Silver et al. 2001, 2005), and thus decreasing leaching and denitrification losses. At an ecosystem level, N- retention would occur if the rates of DNRA and $\mathrm{NH}_{4}{ }^{+}$uptake exceed $\mathrm{N}$ losses from the $\mathrm{NO}_{3}{ }^{-}$pool via denitrification or leaching.

The majority of the $\mathrm{N}$ transformations in terrestrial ecosystems are controlled by microbes, and thus the rates of $\mathrm{N}$ cycling, as well as $\mathrm{N}$ retention and loss, may be related to the composition of the soil microbial community. Linking microbial community characteristics with 
rate processes is challenging, particularly in tropical soils known for their exceptionally high biodiversity and complexity (Borneman and Triplett. 1997). However, general relationships between soil microbial community characteristics and soil $\mathrm{N}$ fluxes may provide new insights into patterns of soil $\mathrm{N}$ retention and loss (Balser and Firestone 2005, Pett-Ridge et al. 2006), and is a critical first step in linking microbial community composition with functional attributes of ecosystems.

In this study we explored mechanisms of $\mathrm{N}$ retention and loss in a humid tropical forest on highly weathered soils. We used stable isotope tracers to follow the fate of $\mathrm{N}$ through the dominant internal $\mathrm{N}$ cycling processes as well as $\mathrm{N}_{2} \mathrm{O}$ emissions over $24 \mathrm{~h}$, and to determine the amount of $\mathrm{N}$ ultimately assimilated or lost via leaching and denitrification to $\mathrm{N}_{2} \mathrm{O}$ over 7 days. Our measurements of process rates allow us to provide an estimate for the potential role of internal biological processes in retaining $\mathrm{N}$, as well as a comparison of plant vs microbial sinks for $\mathrm{N}$ in tropical forest soils. Finally, we generated soil microbial 'fingerprints' to determine whether spatial or temporal $\mathrm{N}$ dynamics could be linked to patterns in belowground microbial community composition.

\section{Study Site}

The study was conducted in the Luquillo Experimental Forest (LEF), a National Science Foundation sponsored Long Term Ecological Research Site in northeastern Puerto Rico (Lat. $18^{\circ} 30^{\prime} \mathrm{N}$; Long. $65^{\circ} 80^{\prime} \mathrm{W}$ ). Sites occur within the subtropical lower montane wet forest life zone, which receives approximately $4500 \mathrm{~mm}$ of rainfall annually and has an average annual temperature of $18.5^{\circ} \mathrm{C}$, both with little temporal variation throughout the year (Weaver and Murphy 1990). The study sites were located on soils derived from volcanoclastic sediments 
(ultisols) with high clay content (up to $70 \%$ ). This forest (referred to here as TMF) has approximately 40 tree species per hectare $>10 \mathrm{~cm}$ diameter at breast height (Brown et al. 1983), and is dominated by Cyrilla racemiflora $\mathrm{L}$.

We established three $10 \times 30 \mathrm{~m}$ plots hereafter referred to as TMF 2, TMF 4, and TMF Icacos. Plots were located within a $1 \mathrm{~km}^{2}$ area at $650-750 \mathrm{~m}$ elevation. The TMF 2 and 4 plots are part of on-going studies of $\mathrm{N}$ and C cycling in humid tropical forest soils (Silver et al. 1999, 2001, 2005, Pett-Ridge and Firestone 2005, Teh et al. 2005, Pett-Ridge et al. 2006). The TMF Icacos site is part of a long-term study of catchment-scale N cycling (McDowell et al. 1992). The plots have similar rainfall, elevation, slope, and plant cover. They differed slightly in soil moisture, total $\mathrm{N}$, total $\mathrm{C}$, and $\mathrm{C}: \mathrm{N}$ ratio representing some of the inherent spatial heterogeneity of the ecosystem (Table 1).

\section{Methods}

\section{${ }^{15} \mathrm{~N}$ Field Experiment}

To determine the competitive strengths of internal $\mathrm{N}$ cycling pathways, leaching and denitrification to $\mathrm{N}_{2} \mathrm{O}$, we separately added ${ }^{15} \mathrm{NH}_{4}{ }^{+}$and ${ }^{15} \mathrm{NO}_{3}{ }^{-}$tracers to root ingrowth cores in each of our 3 plots and measured $\mathrm{N}$ cycling processes and fates after $24 \mathrm{~h}$. We measured assimilation into roots and microbial biomass on additional cores after $7 \mathrm{~d}$, as well as leaching and $\mathrm{N}_{2} \mathrm{O}$ losses. Plots were randomly subdivided into 2 sections and assigned to either ${ }^{15} \mathrm{NH}_{4}^{+}$or ${ }^{15} \mathrm{NO}_{3}{ }^{-}$label addition to prevent cross-contamination.

Unlike most ${ }^{15} \mathrm{~N}$ tracer experiments that use harvested soil or intact cores with excised roots (Booth et al. 2005), root ingrowth cores allowed us to estimate $\mathrm{N}$ cycling processes in the presence of active live roots. Cores $(9 \mathrm{~cm}$ diameter; $10 \mathrm{~cm}$ depth) were constructed from $2 \mathrm{~mm}$ 
nylon mesh on the sides and root exclusion cloth on the bottom; a subset of cores was fitted with disk lysimeters on the bottom in place of root exclusion cloth. We sampled soils using a soil corer the same size as the ingrowth cores. All coarse roots $(\geq 2 \mathrm{~mm})$, and as many fine roots as possible, were removed by hand picking prior to repacking the cores to field bulk density. Packed cores were then placed back into the same holes from which they were taken. Cores were placed in the field $\geq 1 \mathrm{~m}$ apart and assigned to experimental categories for two labels $\left({ }^{15} \mathrm{NH}_{4}^{+}\right.$, $\left.{ }^{15} \mathrm{NO}_{3}{ }^{-}\right)$and two incubation periods ( $24 \mathrm{~h}$, and $\left.1 \mathrm{wk}\right)$. All experimental cores were inserted in December 2001 and allowed to equilibrate over an 11-month period before the ${ }^{15} \mathrm{~N}$ tracer experiment began in November 2002. At the time of the experiment, 10 cores per plot were used to determine background levels of soil moisture, $\mathrm{C}, \mathrm{N}$, microbial biomass $\mathrm{N}, \mathrm{N}_{2} \mathrm{O}$ fluxes, and natural abundance $\delta^{15} \mathrm{~N}$. We destructively sampled a subset of ingrowth cores in June ( $\mathrm{n}=3$ per plot), October ( $n=3$ per plot) and November $2002(n=10$ per plot) to estimate root ingrowth over time. To determine root biomass, soils were extruded from ingrowth cores and washed through three sieves of successively smaller pore sizes $($ all $<1 \mathrm{~mm})$. Roots were then handpicked, sorted as live or dead based on visual characteristics and tensile strength, and then dried at $65{ }^{\circ} \mathrm{C}$ and weighed. We report on fine roots $<2 \mathrm{~mm}$ diameter here. During the 11 -month period of root ingrowth, total fine root biomass initially increased and then stabilized in the last 2 months. The mass of total fine roots (live + dead) at the time of label addition (November 2002) was $59 \pm 4 \%$ of the background root biomass (live + dead roots) in Dec. 2001, and did not differ among plots or treatments (ANOVA, $P=0.38$ for ${ }^{15} \mathrm{NH}_{4}{ }^{+} \mathrm{Vs}^{15} \mathrm{NO}_{3}{ }^{-}$). At the time of the ${ }^{15} \mathrm{~N}$ addition, there was approximately $160 \mathrm{~g} \mathrm{~m}^{-2}$ live fine roots, which is similar to the live fine root biomass of surface soils at a lower elevation in this forest (approximately $170 \mathrm{~g} \mathrm{~m}^{-2}$, Silver and Vogt 1993). 
To estimate patterns of near surface leaching, we fitted the bottom of 10 ingrowth cores per plot (five per label) with $9 \mathrm{~cm}$ diameter disk tension lysimeters (Prenart Soil Disc Samplers, Prenart Equipment, Frederiksberg, Denmark). Cores with lysimeters were among those incubated for one week following ${ }^{15} \mathrm{~N}$ label addition. Lysimeters were maintained under tension (20 PSI) throughout the duration of the 7-day experimental period.

The ${ }^{15} \mathrm{~N}$ label experiment was carried out in November 2002. We injected ${ }^{15} \mathrm{NH}_{4}{ }^{+}$or ${ }^{15} \mathrm{NO}_{3}{ }^{-}\left(>99\right.$ atom $\left.\%{ }^{15} \mathrm{~N}\right)$ at rates of 4.60 and $0.92 \mu \mathrm{g} \mathrm{N} / \mathrm{g}$ soil, respectively, to individual cores. The ${ }^{15} \mathrm{~N}$ addition rates were determined from previous studies in this forest (Silver et al. 2001) and brought the labeled pools to approximately 30.6 atom $\%{ }^{15} \mathrm{~N}^{-\mathrm{NH}_{4}}{ }^{+}$and 5.3 atom $\%{ }^{15} \mathrm{~N}_{-} \mathrm{NO}_{3}{ }^{-}$ , which optimized the ${ }^{15} \mathrm{~N}$ signal while minimizing perturbation of the standing $\mathrm{N}$ pools. Adding different amounts of label was thus necessary, but could have had additional impacts on $\mathrm{N}$ cycling estimates. Kirkham and Bartholomew (1954) and laws of first order kinetics argue that gross rates should not be affected by the size of the product pool. The other processes (uptake, $\mathrm{N}_{2} \mathrm{O}$ fluxes, leaching, DNRA) may have been, and thus label additions could result in overestimates in uptake and leaching, particularly following the $\mathrm{NH}_{4}{ }^{+}$label additions.

The ${ }^{15} \mathrm{~N}$ labeling solution was added with a syringe to each core in six $1 \mathrm{ml}$ injections. The injections were distributed evenly throughout the core volume. We destructively sampled a set of soil cores ( $n=5$ per plot) immediately following the ${ }^{15} \mathrm{~N}$ addition to collect our $\mathrm{T}_{0}$ samples. We sampled gases at $24 \mathrm{~h}$ and 1 week. These cores were fitted with removable static chamber tops to measure ${ }^{15} \mathrm{~N}_{2} \mathrm{O}$ fluxes across the soil-atmosphere interface. Nitric oxide (NO) fluxes from these soils have been shown to be negligible (probably due to high soil moisture, Erickson et al. 2001), and therefore were not measured in this study. For gas fluxes, we collected $60 \mathrm{ml}$ of headspace gas four times over $1 \mathrm{~h}$ from each core chamber (992 $\mathrm{ml}$ volume). Gas 
samples were injected into two pre-evacuated $20 \mathrm{ml}$ Wheaton vials fitted with geomicrobial septa.

At each harvest time point, a subset of 10 cores per label was removed from each plot. Soils were extruded into plastic bags and immediately hand picked for the subsample of root biomass used for tissue ${ }^{15} \mathrm{~N}$ analysis as an estimate of root uptake. The remaining soil was processed in the field and lab for determination of gravimetric moisture content, microbial biomass ${ }^{15} \mathrm{~N}$, microbial community composition, gross $\mathrm{N}$ transformations, DNRA, and total soil ${ }^{15} \mathrm{~N}$ content.

\section{Analytical methods}

Initial processing of samples was done in the field and at the International Institute of Tropical Forestry laboratory, part of the USDA Forest Service in Puerto Rico. Final processing and analyses were conducted at UC Berkeley. For mineral ${ }^{15} \mathrm{~N}$ pool determination, a $60 \mathrm{~g}$ ovendry equivalent (ODE) sample was measured into $162 \mathrm{ml}$ of $2 \mathrm{M} \mathrm{KCl}$ in the field. Samples were shaken for 60 minutes, filtered and stored frozen until analyses were conducted. We determined $\mathrm{NH}_{4}{ }^{+}$and $\mathrm{NO}_{3}{ }^{-}$concentrations colorimetrically (Lachat QuikChem 8000 Flow Injector Analyzer, Latchat-Zellwger Instruments, Milwaukee WI USA). Extracts were prepared for isotope analysis by diffusion (Herman et al. 1995), and $\mathrm{N}$-isotope ratios were measured using an automated nitrogen-carbon analyzer coupled to an isotope ratio mass spectrometer (ANCA-IRMS; PDZ Europa Limited, Crew, UK). Gravimetric soil moisture was determined for all soil samples by drying $10 \mathrm{~g}$ soil at $105^{\circ} \mathrm{C}$ to a constant weight.

Gross mineralization and gross nitrification rates were determined for the soil cores taken at $24 \mathrm{~h}$ according to Kirkham and Bartholomew (1954) and Hart et al. (1994). We also calculated 
rates of DNRA over the first $24 \mathrm{~h}$ using the soil cores that received ${ }^{15} \mathrm{NO}_{3}{ }^{-}$according to Silver et al (2005). Briefly, DNRA was determined as the difference in the ${ }^{15} \mathrm{NH}_{4}{ }^{+}$atom $\%$ between sampling periods, multiplied by the mean $\mathrm{NH}_{4}{ }^{+}$pool size during the interval, and corrected for the mean residence time of the $\mathrm{NH}_{4}{ }^{+}$pool during the interval. This was then divided by the mean ${ }^{15} \mathrm{NO}_{3}{ }^{-}$atom \% during the interval to account for the isotopic composition of source pool. We estimated mean residence times of the ${ }^{15} \mathrm{NH}_{4}{ }^{+}$pool by dividing the initial $\mathrm{NH}_{4}{ }^{+}$pool $(\mu \mathrm{g} / \mathrm{g})$ by the rate of gross consumption in days using data from the ${ }^{15} \mathrm{NH}_{4}{ }^{+}$additions (Silver et al. 2001, 2005).

We determined $\mathrm{N}_{2} \mathrm{O}$ concentration by gas chromatography using a 63Ni detector (GC 8610 c SRI Instruments, Torrence CA USA), and determined ${ }^{15} \mathrm{~N}_{2} \mathrm{O}$ gas isotope ratios using a trace gas module coupled to an IRMS. Rates of $\mathrm{N}_{2} \mathrm{O}$ flux were estimated after correction for changes in the ${ }^{15} \mathrm{NO}_{3}{ }^{-}$source pool (by dividing by the mean ${ }^{15} \mathrm{NO}_{3}{ }^{-}$excess atom \%) over time to make them comparable to other measured $\mathrm{N}$ fluxes. Also for comparative purposes, we report $\mathrm{N}_{2} \mathrm{O}$ fluxes as $\mu \mathrm{g} \mathrm{N}_{2} \mathrm{O}-\mathrm{N} / \mathrm{g} / \mathrm{d}$ using the mass of soil in the core volume.

Root uptake was estimated as the change in ${ }^{15} \mathrm{~N}$ recovered in biomass divided by the average atom $\%{ }^{15} \mathrm{~N}$ of available $\mathrm{NH}_{4}{ }^{+}$and $\mathrm{NO}_{3}{ }^{-}$pools over the 24-hour interval. Samples of lysimeter soil solution were digested with persulfate to determine the concentration of total dissolved $\mathrm{N}$ in leachate (Cabrera and Beare 1993) and diffused to determine ${ }^{15} \mathrm{~N}$ content (Herman et al. 1995). We calculated rates of $\mathrm{N}$ leaching by assuming only vertical flow of water through the soil core over the 7-day experimental period. Although this is a largely untested assumption, we did not detect significant amounts of enriched ${ }^{15} \mathrm{~N}$ in soils immediately outside of the cores. In a separate, small study we compared ${ }^{15} \mathrm{~N}$ of bulk soils at the center of the cores $\left(230 \pm 50 \%{ }^{15} \mathrm{~N}\right)$ to soils 5 to $15 \mathrm{~cm}$ horizontal distance from the center of the cores $(6.1 \pm 1.3$ 
${ }_{00}^{15} \mathrm{~N}$ ). For comparison with other fluxes, we divided the mass of $\mathrm{N}$ in the lysimeter solution by the total mass of soil in each ingrowth core to determine the rates of leaching per unit soil. Our estimate of water volume leached is an upper estimate since we used tension lysimeters, which can pull water from a larger volume of soil water than just the soil above it.

We determined soil microbial biomass ${ }^{15} \mathrm{~N}$ at the 24-hour and 7-day sampling points using the chloroform fumigation method (Cabrera and Beare 1993). Specifically, we divided subsamples into 2 aliquots. One aliquot was extracted immediately in $0.5 \mathrm{M} \mathrm{K}_{2} \mathrm{SO}_{4}$; the other fumigated with ethanol-free chloroform for 5 days before extraction and digestion. Twenty five $\mathrm{ml}$ extracts were digested with $25 \mathrm{ml}$ potassium persulfate, tightly capped and autoclaved for 40 minutes. Microbial biomass $\mathrm{N}$ was calculated as the difference in total dissolved $\mathrm{N}$ between the fumigated and unfumigated soils (Brookes et al. 1985; Vance et al. 1987). Microbial N uptake was estimated as the change in ${ }^{15} \mathrm{~N}$ recovered in biomass divided by the average atom $\%{ }^{15} \mathrm{~N}$ of available $\mathrm{NH}_{4}{ }^{+}$and $\mathrm{NO}_{3}{ }^{-}$pools over the 24 -hour interval. $\%{ }^{15} \mathrm{~N}$ recovery from all pools was calculated as the mass of ${ }^{15} \mathrm{~N}$ label divided by the amount added at the beginning of the experimental period.

For microbial community analysis, we used Terminal Restriction Fragment Length Polymorphism analysis (TRFLP) (Blackwood et al. 2003). One g of homogenized soil from each replicate core collected at time zero from each of the three forest types was sampled and immediately frozen in dry ice until returned to the lab and stored at $-80^{\circ} \mathrm{C}$ until analysis. Community analysis was performed on the cores to which labeled $\mathrm{NH}_{4}{ }^{+}$had just been added. DNA extraction and TRFLP profiling procedures follow those in Pett-Ridge and Firestone (2005), with minor modifications. Briefly, extracted DNA was amplified with 8 replicate PCR amplifications, performed at a range of annealing temperatures from $49-55^{\circ} \mathrm{C}$. Bacterial $16 \mathrm{~S}$ 
rRNA PCR products were cleaned up using a Qiagen PCR Miniprep Kit (Qiagen Sciences, Valencia, CA). MspI restriction digests were performed overnight with $400 \mathrm{ng}$ PCR product in a reaction mixture containing $2 \mathrm{u}$ restriction enzyme and appropriate buffers. Electrophoresis of amplicons and GeneScan 500-ROX size standards (Applied Biosystems, Foster City CA) was performed on an ABI 3100 automated capillary sequencer (Applied Biosystems, Foster City CA).

\section{Statistical Analysis}

Individual cores were treated as independent samples for ${ }^{15} \mathrm{~N}$ analyses for roots, microbial biomass, bulk soil, gas and leachate $(n=10$ per plot). Mineral $\mathrm{N}$ flux rates could not be determined from individual cores because the analysis required destructive harvests at each time point, and flux rates were determined from multiple (unpaired) randomly selected cores over time. Thus, we averaged the $\mathrm{N}$ and ${ }^{15} \mathrm{~N}$ pool size for soil $\mathrm{NH}_{4}{ }^{+}$and $\mathrm{NO}_{3}{ }^{-}$within each sampling point for each plot prior to calculation of DNRA and gross $\mathrm{N}$ cycling rates $(\mathrm{n}=3)$ (Silver et al. 2001, 2005). We conducted one-way analyses of variance (ANOVA) using SAS JMP software (Version 3.2.5, 1999) with ingrowth core as the experimental unit for analyses of ${ }^{15} \mathrm{~N}$ in roots, microbial biomass, bulk soil, gas and leachate. We used experimental plot as the experimental unit for ANOVAs in the analyses of DNRA and gross $\mathrm{N}$ cycling rates. Data that were not normally distributed were log-transformed prior to statistical analysis to meet the assumptions for ANOVA.

Microbial fingerprint TRFLP data from the MspI digest were analyzed with PCORD v4 (MJM Software Design, Gleneden Beach, OR) according to guidelines described in Pett-Ridge 
and Firestone (2005) and Pett-Ridge et al. (2006). Principle components analysis was chosen for the TRFLP data because it is well suited for environmental data (McCune and Grace 2002). The cross-products matrix was constructed using the variance/covariance method, which centers the data but does not standardize the column variables (TRFs). The scores for samples were calculated by weighted averaging. ANOVA and Tukey pairwise comparison tests were used to test for significant differences between treatments. One sample each from the TMF 2 and TMF 4 sites failed quality control guidelines following sequencing and was therefore dropped from the analysis. To examine correlations among environmental variables or $\mathrm{N}$-cycling rates and microbial community structure (represented by principal components) we used multiple regressions using JMP software (SAS Institute, Inc., Cary, North Carolina, USA; see Balser and Firestone 2005 for further discussions of this technique). Regression analysis of environmental variables against principle components scores was done using data collected in ${ }^{15} \mathrm{~N}-\mathrm{NH}_{4}{ }^{+}$label cores, except nitrification and DNRA, which were from cores that received ${ }^{15} \mathrm{~N}_{-} \mathrm{NO}_{3}{ }^{-}$label. In order to examine potential correlations between the microbial communities and $\mathrm{N}$ cycling rates, we used the average value across each plot for ${ }^{15} \mathrm{~N} \mathrm{NH}_{4}{ }^{+}$and $\mathrm{NO}_{3}{ }^{-}$at the $\mathrm{T}_{0}$ sampling point and determined a $\mathrm{N}$ cycling rate on a 'per core' basis using the $\mathrm{N}$ and ${ }^{15} \mathrm{~N}$ content at the $\mathrm{T}_{24}$ hour sampling point. Joint biplot scores for secondary environmental variables and fluxes were plotted on top of ordinations; scores with an approximate $\mathrm{r}^{2}$ value of 0.20 or higher are presented. Significance was determined as $P<0.05$ unless otherwise noted.

\section{Results}

Fates of ${ }^{15} N$ over 24 hours 
The mean residence time for both $\mathrm{NH}_{4}{ }^{+}$and $\mathrm{NO}_{3}{ }^{-}$was less than one day (Table 2). Gross mineralization rates averaged $1.99 \pm 0.77 \mu \mathrm{g} \mathrm{g}^{1} \mathrm{~g}^{-1}$ over the first 24 hours (values reported are mean \pm standard error of 3 forest plots; Figure 1, Table 2). The dominant fate of $\mathrm{NH}_{4}{ }^{+}$was $\mathrm{NO}_{3}{ }^{-}$ (Figure 1; Table 2). Gross nitrification averaged $1.34 \pm 0.48 \mu \mathrm{g} \mathrm{g}^{-1} \mathrm{~d}^{-1}$, approximately $65 \%$ of gross mineralization. Microbial uptake of $\mathrm{NH}_{4}-\mathrm{N}$ and $\mathrm{NO}_{3}-\mathrm{N}$ was not significantly different from zero $\left(0.099 \pm 0.34\right.$ and $0.10 \pm 0.25 \mu \mathrm{g} \mathrm{g}^{-1} \mathrm{~d}^{-1}$, respectively; Figure 2a). The rate of root ${ }^{15} \mathrm{NH}_{4}{ }^{+}$ uptake was $0.45 \pm 0.17 \mu \mathrm{g} \mathrm{g}^{-1} \mathrm{~d}^{-1}$. Root uptake of ${ }^{15} \mathrm{NO}_{3}{ }^{-}$was approximately $24 \%$ of ${ }^{15} \mathrm{NH}_{4}{ }^{+}$ uptake $\left(0.11 \pm 0.017 \mu \mathrm{g} \mathrm{g}^{-1} \mathrm{~d}^{-1} ;\right.$ Figures 1 and 2$)$. Although not statistically significant $(P=0.09)$, root biomass was a larger sink than microbial biomass following ${ }^{15} \mathrm{NH}_{4}{ }^{+}$addition. Similarly, root biomass was a larger sink for added ${ }^{15} \mathrm{NO}_{3}^{-}\left(2.37 \pm 0.75 \%{ }^{15} \mathrm{~N}\right.$ recovery) than microbial biomass $\left(0.69 \pm 3.02 \%{ }^{15} \mathrm{~N}\right.$ recovery $)$, but this pattern was also not statistically significant $(P>0.05)$. $\mathrm{N}_{2} \mathrm{O}$ production accounted for a very small proportion of the added ${ }^{15} \mathrm{NO}_{3}{ }^{-}$label during the first $24 \mathrm{~h}$ (Table 2). Rates of DNRA averaged $0.47 \pm 0.40 \mu \mathrm{g} \mathrm{g}^{-1} \mathrm{~d}^{-1}$ and were approximately $35 \%$ the rate of $\mathrm{NO}_{3}{ }^{-}$production (Table 2, Figure 1). Although spatially variable, DNRA rates exceeded rates of $\mathrm{N}_{2} \mathrm{O}$ production from the $\mathrm{NO}_{3}{ }^{-}$label by approximately two orders of magnitude $(P<$ $0.05)$

Nitrogen uptake and losses over seven days

After 7 days, there was detectable ${ }^{15} \mathrm{~N}$ in microbial biomass from the ${ }^{15} \mathrm{NH}_{4}{ }^{+}$label $(0.083$ $\pm 0.022 \mu$ g excess ${ }^{15} \mathrm{~N} \mathrm{~g} \mathrm{soil}{ }^{-1}$; Figure 2), but not from the ${ }^{15} \mathrm{NO}_{3}{ }^{-}$label. There was more root uptake from the ${ }^{15} \mathrm{NH}_{4}{ }^{+}$label compared to the ${ }^{15} \mathrm{NO}_{3}{ }^{-}$label at day $7(P<0.001)$. The roots were a significant sink for ${ }^{15} \mathrm{~N}$ from the ${ }^{15} \mathrm{NH}_{4}{ }^{+}$label $\left(0.19 \pm 0.051 \mu \mathrm{g}\right.$ excess ${ }^{15} \mathrm{~N}$ g soil $\left.{ }^{-1}\right)$, but not the ${ }^{15} \mathrm{NO}_{3}{ }^{-}$label. Root biomass was a significantly larger sink for added ${ }^{15} \mathrm{NH}_{4}{ }^{+}$and ${ }^{15} \mathrm{NO}_{3}{ }^{-}(6.28 \pm$ 
1.05 and $3.90 \pm 1.03 \%{ }^{15} \mathrm{~N}$ recovery for $\mathrm{NH}_{4}{ }^{+}$and $\mathrm{NO}_{3}{ }^{-}$respectively) than microbial biomass $\left(1.91 \pm 0.52\right.$ and $0.26 \pm 0.83 \%{ }^{15} \mathrm{~N}$ recovery for $\mathrm{NH}_{4}{ }^{+}$and $\mathrm{NO}_{3}{ }^{-}$respectively; $\left.P<0.05\right)$.

Lysimeter samples taken at 7 days indicated that a small amount of ${ }^{15} \mathrm{NO}_{3}{ }^{-}$leaching occurred $\left(0.048 \pm 0.024 \mu \mathrm{g} \mathrm{g}^{-1} \mathrm{~d}^{-1}\right)$, and an even smaller amount of ${ }^{15} \mathrm{NH}_{4}{ }^{+}$leached out of the soils $\left(0.015 \pm 0.007 \mu \mathrm{g} \mathrm{g}^{-1} \mathrm{~d}^{-1}\right)$. Nitrous oxide fluxes from label additions were extremely low in both ${ }^{15} \mathrm{NH}_{4}{ }^{+}$and ${ }^{15} \mathrm{NO}_{3}{ }^{-}$labeled cores $\left(<0.001 \mu \mathrm{g} \mathrm{g}^{-1} \mathrm{~d}^{-1}\right)$.

\section{Microbial community patterns}

Microbial community profiling by TRFLP revealed a diverse microbial assemblage with 143 distinct terminal restriction fragments (TRFs). Following ordination, $50 \%$ of the data variance could be explained on the first two principal component axes. Secondary analysis by regression of environmental variables and rate processes against the first two principle components (PC) axes revealed weak (though statistically significant) correlations among environmental variables, $\mathrm{N}$ cycling rates and shifts in microbial community structure. The variables that correlated best with the microbial community first principal component axis were gross nitrification $\left(\mathrm{R}^{2}=0.2, P<0.03\right)$ and $\mathrm{N}_{2} \mathrm{O}$ flux $\left(\mathrm{R}^{2}=0.22, P<0.01\right)$. Gross nitrification was also significantly correlated with the second principal component axis $\left(\mathrm{R}^{2}=0.18, P<0.02\right)$. We measured as much community variability within sites as across sites (Figure 3). The most significant correlates differed when analyzed on a site by site basis. In TMF 2, with its relatively drier soils and significantly higher gross nitrification rates, soil moisture was most closely aligned with the microbial community patterns $\left(\mathrm{R}^{2}=0.2, P<0.051\right)$. In TMF 4 , where soil moisture was higher, the strongest correlates with microbial community patterns were $\mathrm{N}_{2} \mathrm{O}$ flux, root recovery and gross nitrification $\left(\mathrm{R}^{2}=0.6,0.4,0.2, P<0.001,0.054,0.003\right.$, respectively). In 
the TMF Icacos site, the strongest correlate was soil $\mathrm{C}: \mathrm{N}\left(\mathrm{R}^{2}=0.6, P<0.011\right)$.

\section{Discussion}

Nitrogen Retention and Loss: A Soil Nitrogen Budget

We present a relatively complete budget for soil N-cycling in this tropical forest (Figure 1). The gross rates of $\mathrm{NH}_{4}{ }^{+}$production averaged $1.99 \pm 0.77 \mu \mathrm{g} \mathrm{g}^{-1} \mathrm{~d}^{-1}$. If we sum the direct fates of $\mathrm{NH}_{4}{ }^{+}$(nitrification, microbial uptake, root uptake and leaching), the resulting value of $1.90 \pm$ $0.37 \mu \mathrm{g} \mathrm{g}^{-1} \mathrm{~d}^{-1}$ agrees quite well with the value for gross mineralization determined by pool dilution. The measured rates of gross mineralization include all ${ }^{14} \mathrm{~N}$ entering the $\mathrm{NH}_{4}{ }^{+}$pool (including DNRA). The dominant fate for $\mathrm{NH}_{4}{ }^{+}$in this system was nitrification with a rate of $1.34 \pm 0.48 \mu \mathrm{g} \mathrm{g}^{-1} \mathrm{~d}^{-1}$. Summing the measured fates of $\mathrm{NO}_{3}^{-}$(root uptake, microbial uptake, denitrification to $\mathrm{N}_{2} \mathrm{O}$, leaching and DNRA) yields a value of $0.74 \pm 0.55 \mu \mathrm{g} \mathrm{g}^{-1} \mathrm{~d}^{-1}$, accounting for approximately $55 \%$ of the rate of $\mathrm{NO}_{3}{ }^{-}$production. The fate of the remaining $45 \%$ of $\mathrm{N}$ entering the $\mathrm{NO}_{3}{ }^{-}$pool is likely to have been lost as $\mathrm{N}_{2}$ in these humid, C-rich soils. The fate of the remaining $22 \%$ of the $\mathrm{NH}_{4}^{+}$produced is unclear, but could be uptake by plant roots and movement into aboveground pools or outside of the plots. We discuss the likelihood of these below. Not accounting for $100 \%$ of ${ }^{15} \mathrm{~N}$ applied is a common challenge in tracer experiments. The lack of complete recovery does not alter our basic conclusions since we document the relative importance of several important soil processes.

Nitrate reduction via DNRA does not, in itself, serve as a $\mathrm{N}$ retention mechanism unless the $\mathrm{NH}_{4}{ }^{+}$produced is assimilated into plants and/or microbial biomass. Assimilation would take the $\mathrm{N}$ "out of play" over the short-term, decreasing the chances for re-nitrification and subsequent loss via denitrification and leaching. At a system level, $\mathrm{N}$ retention occurs when $\mathrm{N}$ 
uptake exceeds $\mathrm{N}$ losses. In this study DNRA reduced approximately $0.47 \mu \mathrm{NO}_{3}-\mathrm{N} \mathrm{g}^{-1} \mathrm{~d}^{-1}$ to $\mathrm{NH}_{4}{ }^{+}$, and roots took up approximately the same amount of $\mathrm{NH}_{4}{ }^{+}$over a $24 \mathrm{~h}$ period. In contrast, $\mathrm{N}_{2} \mathrm{O}$ production combined with leaching from the ${ }^{15} \mathrm{NO}_{3}{ }^{-}$labeled cores (assuming similarity between $24 \mathrm{~h}$ and $7 \mathrm{~d}$ rates) resulted in the loss of only $0.056 \mu \mathrm{g} \mathrm{NO}_{3}-\mathrm{N} \mathrm{g}^{-1} \mathrm{~d}^{-1}$. If we assume that all of the remaining $\mathrm{NO}_{3}{ }^{-}$produced was denitrified to $\mathrm{N}_{2}$ (a liberal assumption as some may have been reduced to organic $\mathrm{N}$ (Dail et al. 2001, although see Coleman et al. 2007) then $\mathrm{NO}_{3}{ }^{-}$losses amounted to $0.66 \mu \mathrm{g} \mathrm{g}^{-1} \mathrm{~d}^{-1}$. Rates of DNRA and subsequent $\mathrm{NH}_{4}{ }^{+}$uptake decreased the potential $\mathrm{NO}_{3}{ }^{-}$losses. The absence of DNRA would likely increase $\mathrm{N}$ losses by $40 \%$ (assuming similar rates of plant and microbial uptake as currently observed) to $72 \%$ (if all of the additional $\mathrm{NO}_{3}{ }^{-}$ was lost via leaching and denitrification). It is important to note that these estimates do not account for the response of plant and microbial processes to changes in $\mathrm{NO}_{3}{ }^{-}$concentrations.

\section{Gross $N$ cycling and $N$ uptake}

Few data are available gross $\mathrm{N}$ transformations for tropical forests. Our rates of gross mineralization fall at the low end of the range of estimates of gross mineralization in tropical forest soils reviewed by Booth et al. (2005). This may result from the fact that most other assays were likely conducted with severed roots in the field or under laboratory settings where soil disturbance is likely to increase mineralization rates. Our rates of gross nitrification fall within the range found in other tropical forest soils (Booth et al. 2005), and highlight the large and rapid throughput of organic $\mathrm{N}$ to $\mathrm{NO}_{3}^{-}$.

We are not aware of any studies that have measured in situ plant $\mathrm{N}$ uptake in tropical forest soils, or any that have compared plant versus microbial $\mathrm{N}$ assimilation. Our results show that root uptake of ${ }^{15} \mathrm{NH}_{4}{ }^{+}$and ${ }^{15} \mathrm{NO}_{3}{ }^{-}$was much greater than microbial uptake over the 7 days in 
these soils. We speculate that the fact that root $\mathrm{N}$ uptake exceeded microbial uptake may be a consequence of the high $\mathrm{N}$ availability in these soils, where microbes may be $\mathrm{N}$ saturated while plants may require greater $\mathrm{N}$ uptake for biomass maintenance and growth.

Roots preferred ${ }^{15} \mathrm{NH}_{4}{ }^{+}$over ${ }^{15} \mathrm{NO}_{3}{ }^{-}$uptake in this forest. Plant species differ in their capacity to take up $\mathrm{NH}_{4}{ }^{+}$or $\mathrm{NO}_{3}{ }^{-}$(Gharbi and Hipkin 1984, Crabtree and Bazazz 1993, Horsley 1988, Garnett and Smethurst 1999). Many temperate plants show a strong preference for $\mathrm{NH}_{4}{ }^{+}$ over $\mathrm{NO}_{3}{ }^{-}$(Garnett and Smethurst 1999; Gessler et al. 1998, Wallander et al. 1997). Nitrate is often more available to roots than $\mathrm{NH}_{4}{ }^{+}$due to the high mobility of $\mathrm{NO}_{3}{ }^{-}$in soil water, but may be in low supply relative to $\mathrm{NH}_{4}{ }^{+}$in these tropical forest soils due to the large number of strongly competing sinks. The preference of tropical plant species for $\mathrm{NH}_{4}{ }^{+} \mathrm{vs} \mathrm{NO}_{3}{ }^{-}$can parallel the availability of either form of inorganic N (Houlton et al. 2007). Furthermore, plants must use energy to incorporate $\mathrm{NO}_{3}{ }^{-}$into their amino acids (Gutschick 1981, Smirnoff and Stewart 1985).

Our estimate of plant $\mathrm{N}$ uptake is conservative given that we did not measure movement of $\mathrm{N}$ into aboveground plant biomass or transport by roots outside of the cores. However, we can account for approximately $78 \%$ of the $\mathrm{NH}_{4}{ }^{+}$produced over $24 \mathrm{~h}$. Based on 24-hour root measurements, plant roots in our study took up approximately $0.47 \pm 0.17 \mu \mathrm{g} \mathrm{NH} \mathrm{NH}_{4}-\mathrm{N} \mathrm{g}^{-1} \mathrm{~d}^{-1}$. Plant roots accessed and took up $23 \%$ of $\mathrm{NH}_{4}{ }^{+}$produced during gross mineralization. Plant roots therefore represent a significant sink for $\mathrm{NH}_{4}{ }^{+}$, reducing the likelihood of $\mathrm{N}$ being lost from soils via nitrification and subsequent leaching or denitrification. In addition it is possible that roots in these soils take up $\mathrm{N}$ as amino acids, although the relatively high $\mathrm{N}$ availability in these soils is likely to decrease the importance of this pathway (Schimel and Bennett 2004). Direct root uptake of organic $\mathrm{N}$ from these soils would also serve to reduce $\mathrm{N}$ available for nitrification and subsequent loss from the $\mathrm{NO}_{3}{ }^{-}$pool. 
We found that microbial uptake and assimilation of ${ }^{15} \mathrm{NH}_{4}{ }^{+}$and ${ }^{15} \mathrm{NO}_{3}{ }^{-}$was extremely low within the first 24 h. In 15 tropical forest soils, Vitousek and Matson (1988) found a strong preference for $\mathrm{NH}_{4}{ }^{+}$over $\mathrm{NO}_{3}{ }^{-}$by the microbial biomass, and decreased net $\mathrm{N}$ immobilization, regardless of the form added, with increasing mineral $\mathrm{N}$ concentrations. As with plants, the process of assimilatory $\mathrm{NO}_{3}{ }^{-}$reduction by microbes requires energy for the conversion of $\mathrm{NO}_{3}{ }^{-}$to $\mathrm{NH}_{4}{ }^{+}$, and therefore is metabolically repressed when $\mathrm{NH}_{4}{ }^{+}$is available (Puri and Ashman 1999). In soils with relatively high $\mathrm{NH}_{4}{ }^{+}$availability, such as the tropical forest soils we studied, microbial assimilation of $\mathrm{NO}_{3}{ }^{-}$is often negligible (Vitousek and Matson 1988, Silver et al. 2001, 2005).

We calculated relatively high rates of consumption for $\mathrm{NH}_{4}-\mathrm{N}$ and $\mathrm{NO}_{3}-\mathrm{N}$ (Table 2).

Calculated rates of consumption include several processes including abiotic sinks, gross nitrification (for $\mathrm{NH}_{4}{ }^{+}$), denitrification and DNRA (for $\mathrm{NO}_{3}{ }^{-}$), and microbial and plant $\mathrm{N}$ uptake. Since the calculated rate of consumption includes processes in addition to microbial uptake, it makes sense that our direct measure for microbial uptake was significantly less than that calculated for consumption. These results show the importance of actually measuring microbial $\mathrm{N}$ uptake directly (e.g. fumigation extraction techniques). Similarly low rates of microbial uptake of $\mathrm{N}$ have been found in another study conducted in wet tropical forests of Puerto Rico (Silver et al. 2001).

The Fates of Nitrate: DNRA versus Denitrification to $\mathrm{N}_{2} \mathrm{O}$

We found that $65 \%$ of the $\mathrm{N}$ entering the inorganic $\mathrm{N}$ pool was subsequently nitrified during the first $24 \mathrm{~h}$. This, coupled with the significant potential for $\mathrm{NO}_{3}{ }^{-}$losses from humid tropical forest soils (Lewis et al. 1999, Stehfest and Bouwman 2006), highlights the importance 
of determining the fates of $\mathrm{NO}_{3}{ }^{-}$in order to understand patterns of $\mathrm{N}$ retention and loss in this ecosystem. We measured surprisingly low denitrification to $\mathrm{N}_{2} \mathrm{O}$ from the ${ }^{15} \mathrm{NO}_{3}{ }^{-}$label. Nitrous oxide is an important greenhouse gas and a precursor for stratospheric ozone destruction (Cicerone 1987, Prather et al. 1995). Tropical forests are the largest natural source of $\mathrm{N}_{2} \mathrm{O}$ globally (Stehfest and Bouwman 2007), and $\mathrm{N}_{2} \mathrm{O}$ fluxes from humid soils are thought to be dominated by denitrification (Groffman et al. 1989). In this study, rates of DNRA were approximately $35 \%$ of gross nitrification, and were much greater than rates of $\mathrm{N}_{2} \mathrm{O}$ production from denitrification. DNRA coupled with root and microbial uptake, $\mathrm{N}_{2} \mathrm{O}$ fluxes, and leaching losses explained $55 \%$ of the $\mathrm{NO}_{3}{ }^{-}$produced, leaving $45 \%$ unexplained. We expect that denitrification to $\mathrm{N}_{2}$ is the likely fate of the remaining $\mathrm{NO}_{3}{ }^{-}$. The lower montane subtropical wet forests in the LEF are characterized by variable redox conditions (Silver et al. 1999), high C availability (McGroddy and Silver 2000), and considerable $\mathrm{NO}_{3}{ }^{-}$production (Silver et al. 2001 and this study), all of which contribute to high denitrification potential. High denitrification, coupled with a low $\mathrm{N}_{2} \mathrm{O}$ to $\mathrm{N}_{2}$ ratio would contribute to the low $\mathrm{N}_{2} \mathrm{O}$ fluxes we observed. It is difficult to measure denitrification to $\mathrm{N}_{2}$ in natural terrestrial systems due to the high background $\mathrm{N}_{2}$ concentrations in the atmosphere. Current isotope ratio mass spectrometry analysis of $\mathrm{N}_{2}$ is generally not sufficiently sensitive to detect added ${ }^{15} \mathrm{~N}$ label in relatively low-level tracer experiments (Groffman et al. 2006). New methods for measuring $\mathrm{N}_{2}$ fluxes are needed to better quantify the relative importance of denitrification and DNRA in tropical forests.

\section{Leaching losses}

We found small amounts of $\mathrm{NH}_{4}{ }^{+}$leaching from these soils $\left(0.015 \pm 0.007 \mu \mathrm{g} \mathrm{g}^{-1} \mathrm{~d}^{-1}\right)$. While $\mathrm{NO}_{3}{ }^{-}$losses via leaching were greater, they were still small compared to the other 
processes we measured (Figure 1). There has been research on the loss of stream water $\mathrm{N}$ from tropical forested watersheds (McDowell et al. 1992, 1996, McDowell and Asbury 1994). Approximately $50 \%$ of the total $\mathrm{N}$ exports $\left(\mathrm{NH}_{4}{ }^{+}+\mathrm{NO}_{3}{ }^{-}+\mathrm{DON}+\right.$ particulate $\left.\mathrm{N}\right)$ from tropical watersheds globally are in the form of $\mathrm{NO}_{3}^{-}$(Lewis et al. 1999). Previous research in Puerto Rico shows that export from streams for three forested humid tropical watersheds averaged only $1.6 \pm$ $0.2 \mathrm{~kg} \mathrm{NO}_{3}-\mathrm{N} \mathrm{ha}^{-1} \mathrm{yr}^{-1}$ (McDowell and Asbury 1994). Approximately $3.1 \%$ of $\mathrm{NO}_{3}^{-}$produced via gross nitrification was leached during our week long assay. These relatively low leaching rates are likely a result of the other strong sinks for $\mathrm{NO}_{3}{ }^{-}$which decrease its susceptibility to leaching including DNRA and $\mathrm{N}_{2}$ fluxes.

\section{Microbial Communities}

Nitrogen cycling processes are controlled by the interactions of microbes and their environment. Our data and previous studies have demonstrated considerable spatial and temporal heterogeneity of N cycling processes in tropical forests (Vitousek and Matson 1988; Silver et al. 2001; 2005; Pett-Ridge 2005). Our microbial community data (Figure 3) are consistent with this, showing high variability across sites. In addition, we found considerable variation within sites, particularly in TMF 4 where soil edaphic characteristics such as moisture, iron (Table 1), \% clay, and belowground $\mathrm{N}_{2} \mathrm{O}$ and $\mathrm{CH}_{4}$ production (Pett-Ridge 2005) exhibit a wide range of values. The TRFLP bacterial fingerprints were correlated with $\mathrm{N}$ cycling processes, particularly gross nitrification and denitrification to $\mathrm{N}_{2} \mathrm{O}$. As mentioned above, $\mathrm{NO}_{3}{ }^{-}$production and the fates of $\mathrm{NO}_{3}{ }^{-}$appear to play a particularly important role in $\mathrm{N}$ retention and loss in this ecosystem. It is important to note that while the microbial community data show interesting trends, the correlations were relatively weak. TRFLP is a low resolution approach of characterizing the 
complex microbial community structure, and thus should not be expected to yield strong correlations with specific $\mathrm{N}$ transformations. New techniques promise spatially and temporally explicit, deep phylogenetic and functional analyses of complex microbial communities. Unpublished clone library analysis (pers. comm. E. Brodie) and high density microarray deep phylogenetic analysis of the communities in the TMF-4 site (pers. comm. E. Dubinsky) show an abundance of phylogenetically diverse organisms not previously described. Under the fluctuating redox characteristics of these soils a range of energy-generating metabolisms (from $\mathrm{O}_{2}$ respiration to methanogenesis) are available to these complex communities over time and space. Specific microbial populations possess the appropriate metabolic capacities to exploit specific redox niches. Thus the processes that we measure (e.g., DNRA, denitrification, nitrification) turn on and off in these soils. Their on-phases are controlled in time and space by the localized redox conditions and the localized microbial community composition (Pett-Ridge and Firestone 2005; Pett-Ridge 2005).

\section{Conclusions}

Our research highlights the importance of rapid gross nitrification and the fates of $\mathrm{NO}_{3}^{-}$ in $\mathrm{N}$ retention and loss in humid tropical forest soils. We account for approximately $78 \%$ of the $\mathrm{NH}_{4}{ }^{+}$produced via gross mineralization and found that two thirds of the $\mathrm{NH}_{4}{ }^{+}$produced is converted to $\mathrm{NO}_{3}{ }^{-}$during nitrification over $24 \mathrm{~h}$. Over one third of the $\mathrm{NO}_{3}{ }^{-}$produced is rereduced to $\mathrm{NH}_{4}{ }^{+}$via DNRA where it is available for plant uptake. Rates of DNRA, while spatially variable, were two orders of magnitude greater than $\mathrm{N}_{2} \mathrm{O}$ production from the ${ }^{15} \mathrm{NO}_{3}{ }^{-}$ label. Plant uptake into biomass is the likely fate of the remaining $\mathrm{NH}_{4}{ }^{+}$, while the other possible major fate of $\mathrm{NO}_{3}{ }^{-}$in this system is $\mathrm{N}_{2}$ production. 
Nitrogen deposition rates in the tropics are expected to increase significantly over the next 10 to 20 years (Matthews 1994; Galloway et al. 1994; Holland et al. 1999). Matson et al. (1999) cautions that, unlike some temperate forests, tropical forests are unlikely to act as a greater $\mathrm{C}$ sink with increased $\mathrm{N}$ deposition due to the fact that most tropical forests are limited by nutrients other than N. In fact, Matson et al. (1999) predicts that tropical forests will ultimately respond to increased $\mathrm{N}$ deposition with reduced productivity because of the negative consequences of excess N (e.g., soil acidity, cation loss, etc.). Future research should focus on the fates of $\mathrm{NO}_{3}{ }^{-}$under increased $\mathrm{N}$ deposition scenarios in humid, highly weathered tropical forest soils. Key research needs include a more thorough understanding of the $\mathrm{N}$ retention and loss under increasing $\mathrm{N}$ deposition, and the factors controlling the ratio of $\mathrm{N}_{2}$ and $\mathrm{N}_{2} \mathrm{O}$ during denitrification. 


\section{Acknowledgements}

This research was supported by grants from the Andrew W. Mellon Foundation and the National Science Foundation, Ecosystem Studies Science Cluster to WLS and MKF. Additional support was provided by the NSF-LTER grant to the Luquillo-LTER program and the University of Puerto Rico. This work was conducted as part of project \# CA-B*-ECO-7069-MS of the California Agricultural Experiment Station (WLS). This work was also funded in part under DOE-LBNL contract no. DE-AC02-05CH11231. We thank Don Herman, Violet Herman, Erika Marin-Spiotta, Andy Thompson and Carlos Torrens for help in the field and in the lab. IITF, Ariel Lugo, and Mary Jeane Sanchez graciously supplied infrastructural support in the field and lab. We also thank Eric Dubinsky for help in the field and for generating a good war story. 


\section{Literature Cited}

Balser, T. C. and M. K. Firestone. 2005. Linking microbial community composition and soil processes in a California annual grassland and mixed-conifer forest. Biogeochemistry 73:395-415.

Blackwood, C.B., T. Marsh, S.H. Kim and E.A. Paul. 2003. Terminal restriction fragment length polymorphism data analysis for quantitative comparison of microbial communities. Applied and Environmental Microbiology 69: 926-932.

Booth, M.S., J.M. Stark and E. Rastetter. 2005. Controls on nitrogen cycling in terrestrial ecosystems: a synthetic analysis of literature data. Ecological Monographs 75:139-157.

Borneman J. and E.W. Triplett. 1997. Molecular microbial diversity in soils from eastern Amazonia: evidence for unusual microorganisms and microbial population shifts associated with deforestration. Applied and Environmental Microbiology 63: 2647-2653.

Brookes, P.C., A. Landman, G. Pruden, and D.S. Jenkinson. 1985. Chloroform fumigation and the release of soil nitrogen: A rapid direct extraction method to measure microbial biomass nitrogen in soil. Soil Biology and Biochemistry 17:837-842.

Brown, S., A.E. Lugo, S. Silander and L. Liegel. 1983. Research history and opportunities in the Luquillo experimental forest Puerto Rico. US Forest Serv Gen Tech Rep 44:1-128.

Cabrera, M. L., and M. H. Beare. 1993. Alkaline persulfate oxidation for determining total nitrogen in microbial biomass extracts. Soil Science Society of America Journal 57:10071012.

Cicerone, R. J. 1987. Changes in stratospheric ozone. Science 237: 35-42.

Colman, B. P., N. Fierer, J.P. Schimel. 2007. Abiotic nitrate incorporation in soil: is it real? Biogeochemistry. 84: 161-169 
Crabtree, R. C. and F. A. Bazazz. 1993. Tree seedling response of four birch species to simulated nitrogen deposition: ammonium vs nitrate. Ecological Applications. 3:315-321.

Dail, D.B., E.A. Davidson, and J. Chorover. 2001. Rapid abiotic transformation of nitrate in an acid forest soil. Biogeochemistry 54:131-146.

Davidson, E. A., C. J. Reis de Carvalho, A. M. Figueira, F. Y. Ishida, J. H. B. Ometto, G. B. Nardoto, R. T. Saba, S. N. Hayashi, E. C. Leal, I. C. G. Vieira and L. A. Martinelli. 2007. Recuperation of nitrogen cycling in Amazonian forests following agricultural abandonment. Nature 447, 995-998

Erickson, H. E., M. Keller, and E. A. Davidson. 2001. Nitrogen Oxide Fluxes and Ecosystem Nitrogen Cycling during Postagricultural Succession and Forest Fertilization in the Humid Tropics. Ecosystems 4: 67-84.

Firestone, M. K. and E. A. Davidson. 1989. Microbiological basis of $\mathrm{NO}$ and $\mathrm{N}_{2} \mathrm{O}$ production and consumption in soil. pp 7-21 in M.O. Andreae and D.S. Schimel, eds. Exchange of Trace Gases between Terrestrial Ecosystems and the Atmosphere. John Wiley and Sons Ltd., S. Bernhard, Dahlem Konferenzen.

Galloway, J. N., J. D. Aber, J.W. Erisman, S. P. Seitzinger, R. W. Howarth, E. B. Cowling and B. J. Cosby. 1994. The nitrogen cascade. BioScience 53: 341-356

Garnett, T. P., and P. J. Smethurst. 1999. Ammonium and nitrate uptake by Eucalyptus nitens: Effects of $\mathrm{pH}$ and temperature. Plant and Soil 214: 133-140.

Gessler, A., S. Schneider, D. Von Sengbusch, P. Weber, U. Hanemann, C. Huber, A. Rothe, K. Kreutzer, and H. Rennenberg. 1998. Field and laboratory experiments on net uptake of nitrate and ammonium by the roots of spruce (Picea abies) and beech (Fagus sylvatica) trees. New Phytologist 138:275-285. 
Gharbi, A. and C. Hipkin. 1984. Studies on nitrate reductase in British angiosperms. I. A comparison of nitrate reductase activity in ruderal, woodland-edge and woody species. New Phytology 97:629-639.

Groffman, P. M., and J. M. Tiedje. 1989. Denitrification in north temperate forest soils: relationships between denitrification and environmental factors at the landscape scale. Soil Biology and Biochemistry 21:621-626.

Groffman P. M., M. A. Altabet, J. K Böhlke., K.Butterbach-Bahl, M. B. David., M. K. Firestone, A. E. Giblin, T. M. Kana, L. P. Nielsen and M. A. Voytek.. 2006 Methods for measuring denitrification: diverse approaches to a difficult problem. Ecological Applications: 16: 2091-2122.

Gutschick, V. P. 1981. Evolved strategies in nitrogen acquisition by plants. American Naturalist 118:607-637.

Hall, S. J. and P. A. Matson. 1999. Nitrogen oxide emissions after nitrogen additions in tropical forests. Nature 400:152-155.

Hart, S. C., J. M. Stark, E. A. Davidson and M. K. Firestone. 1994. Nitrogen mineralization, immobilization, and nitrification. Pages 985-1018 in R. W. Weaver, editor. Methods of Soil Analysis, Part 2. Microbiological and Biochemical Properties. Soil Science Society of America, Madison, WI.

Hedin, L. O., J. C. Von Fischer, N. E. Ostrom, B. P. Kennedy, M. G. Brown, and G. P. Robertson. 1998. Thermodynamic constraints on nitrogen transformations and other biogeochemical processes at soil-stream interfaces. Ecology 79: 684-703.

Herman, D. J., P. D. Brooks, M. Ashraf, F. Azam, and R. L. Mulvaney. 1995. Evaluation of methods for nitrogen-15 analysis of inorganic nitrogen in soil extracts. Part 2: Diffusion Methods. Communications in Soil Science and Plant Analysis 26: 1675-1685. 
Herbert, D. A., and J. H. Fownes. 1995. Phosphorus limitation of forest leaf area and net primary production on a highly weathered soil. Biogeochemistry 29: 223-235.

Holland, E. A.,F. J. Dentener, B. H. Braswell, and J. M. Sulzman. 1999. Contemporary and preindustrial global reactive nitrogen budgets. Biogeochemistry 46: 7-43.

Horsley, S.B. 1988. Nitrogen species preference of Prunus serotina Ehrh. and Betula alleghaniensis Britt. seedlings. American Journal of Botany 75:75.

Houlton, B. Z., D. M. Sigman, E. A. G. Schuur, and L. O. Hedin 2007. A climate-driven switch in plant nitrogen acquisition within tropical forest communities. Proceedings of the National Academy Sciences. 104: 8902-8906.

Jackson, L. E., J. P. Schimel, and M. K. Firestone. 1989. Short-term partitioning of nitrate and ammonium between plants and microbial biomass in an annual grassland. Soil Biology and Biochemistry 21:409-415.

Kirkham, D., and W. V. Bartholomew. 1954. Equations for following nutrient transformations in soil, utilizing tracer data. Soil Science Society of America Proceedings 18:33-34.

Lewis, W. M., J. M. Melack, W. H. McDowell, M. McClain, and J. E. Richey. 1999. Nitrogen yields from undisturbed watersheds in the Americas. Biogeochemistry 46: 149-162.

Livingston, G. P., P. M. Vitousek and P. A. Matson. 1988. Nitroux oxide flux and nitrogen transformations across a landscape gradient in Amazonia. Journal of Geophysical Research 93: 1593-1599.

Matson, P. A., W. H. McDowell, A. R. Townsend, and P. M. Vitousek. 1999. The globalization of $\mathrm{N}$ deposition: Ecosystem consequences in tropical environments. Biogeochemistry 46: 67-83. 
Matthews, E. 1994. Nitrogenous fertilizers: Global distribution of consumption and associated emissions of nitrous oxide and ammonia. Global Biogeochemical Cycles 8, 411-439.

McCune, B. and J. B. Grace. 2002. Analysis of Ecological Communities. MjM Software Design, Gleneden Beach, OR.

McDowell, W. H., W. B. Bowden, and C. E. Asbury. 1992. Riparian nitrogen dynamics in two geomorphically distinct tropical forest watersheds: subsurface solute patterns. Biogeochemistry 18:53-75.

McDowell, W. H. and C. A. Asbury. 1994. Export of carbon, nitrogen and major ions from three tropical montane watersheds. Limnography and Oceanography 39:111-125.

McDowell, W. H., C. P. McSwiney, and W. B. Bowden. 1996. Effects of hurricane disturbance on groundwater chemistry and riparian function in a tropical rain forest. Biotropica 28: $577-584$.

McGroddy, M. E. and W. L. Silver. 2007. Nutrient Cycling and Climate Change in Tropical Forests. Pages 295-316 in M. Bush and J. Flenly eds, Tropical Rainforest Responses to Climatic Change. Praxis-Springer Verlag, Berlin.

Melillo, J. M., A. D. McQuire, D. W. Kicklighter, B. I. Moorei, C. J. Vorosmarty, and A. L. Schloss. 1993. Global climate change and terrestrial net primary production. Nature 363: 234-240.

Pett-Ridge, J., W. L. Silver and M. K. Firestone. 2006. Redox fluctuations in a humid tropical forest soil impact $\mathrm{N}$-cycling rates by framing the composition of the soil microbial community. Biogeochemistry 81: 95-110. 
Pett-Ridge, J., 2005. Rapidly Fluctuating Redox Regimes Frame the Ecology of Microbial Communities and Their Biogeochemical Function in a Humid Tropical Soil. Ph.D. Dissertation, University of California, Berkeley (2005).

Pett-Ridge, J. and M. K. Firestone. 2005. Redox fluctuation structures microbial communities in a wet tropical soil. Applied and Environmental Microbiology 71: 6998-7007.

Prather, M. J., R. Derwent, D. Ehhalt, P. Fraser, E. Sanhueza, and X. Zhou.1995. Other trace gases and atmospheric chemistry, in Climate Change 1994 (eds. Houghton, J. T. et al.) 73-126. Cambridge Univ. Press.

Puri, G., and M. R. Ashman. 1999. Microbial immobilization of ${ }^{15}$ N-labelled ammonium and nitrate in a temperate woodland soil. Soil Biology \& Biochemistry 31: 929-931.

Reed, S.C., C. C. Cleveland and A. R. Townsend. 2007. Controls over leaf litter and soil nitrogen fixation in two lowland tropical rain forests. Biotropica 39: 585-592.

Schellekens, J., F. N. Scatena, L. A. Bruijnzeel, A. van Dijk, M. M. A. Groen, and R. J. P. van Hogezand. 2004. Stormflow generation in a small rainforest catchment in the Luquillo Experimental Forest, Puerto Rico. Hydrological Processes 18:505-530.

Schimel, J. P., and J. Bennett. 2004. Nitrogen mineralization: challenges of a changing paradigm. Ecology 85:591-602.

Silver, W. L., and K. A. Vogt. 1993. Fine root dynamics following single and multiple disturbances in a subtropical wet forest ecosystem. Journal of Ecology 8:729-738.

Silver, W. L., A. E. Lugo, and M. Keller. 1999. Soil oxygen availability and biogeochemistry along rainfall and topographic gradients in upland wet tropical forest soils. Biogeochemistry 44:301-328. 
Silver, W. L., D. J. Herman, and M. K. Firestone. 2001. Dissimilatory nitrate reduction to ammonium in tropical forest soils. Ecology 82: 2410-2416.

Silver, W. L., A. W. Thompson M. K. Firestone, A. Reich, and J. J. Ewel. 2005. Nitrogen retention and loss in tropical plantations and old growth forests. Ecological Applications 15: $1604-1614$.

Smirnoff, N. and G. R. Stewart. 1985. Nitrate assimilation and translocation by higher plants; comparative physiology and ecological consequences. Physiol. Plant. 64:133-140.

Stark, J. M., and S. C. Hart. 1997. High rates of nitrification and nitrate turnover in undisturbed coniferous forests. Nature 385: 61-64.

Stehfest, E., and L. Bouwman. 2006. N2O and NO emission from agricultural fields and soils under natural vegetation: summarizing available measurement data and modeling of global annual emissions. Nutrient Cycling in Agroecosystems 74:207-228.

Tanner, E. V. J., V. Kapos, and W. Franco. 1992. Nitrogen and phosphorus fertilization effects on Venezuelan montane forest trunk growth and litterfall. Ecology 73: 78-86.

Teh, Y. A., W. L. Silver, and M. E. Conrad. 2005. Oxygen effects on methane production and oxidation in humid tropical forest soils. Global Change Biology 11:1283-1297.

Templer, P. H., Lovett G. M., Findlay S., Weathers K., Dawson T. 2005. Influence of tree species on forest nitrogen retention in the Catskill Mountains, NY. Ecosystems 8:1-16.

Tiedje, JM. 1988. Ecology of denitrification and dissimilatory nitrate reduction to ammonium. pp. 179-244 in A. J. B. Zehnder, ed. Biology of Anaerobic Microorganisms. WileyInterscience Publication, Canada. 
Vance, E. D., Brookes P. C., Jenkinson D. S. 1987. An extraction method for measuring soil microbial biomass. Soil Biol Biochem. 19:703-707.

Vitousek, P. M., and R. W. Howarth. 1991. Nitrogen limitation on land and in the sea: How can it occur? Biogeochemistry 13: 87-116.

Vitousek, P. M. and P. A. Matson. 1984. Mechanisms of nitrogen retention in forest ecosystems: a field experiment. Science 225:51-52.

Vitousek, P. M., and R. L. Sanford, Jr. 1986. Nutrient Cycling in Moist Tropical Forest. pp. 137168.

Vitousek, P. M., and H. Farrington. 1997. Nutrient limitation and soil development: Experimental test of a biogeochemical theory. Biogeochemistry 37: 63-75.

Vitousek, P. M. and P. A. Matson. 1988. Nitrogen transformations in a range of tropical forest soils. Soil Biology and Biochemistry 20:361-367.

Vitousek, P. M, K. Cassman, C. Cleveland, T. Crews, C. B. Field, N. B. Grimm, R. W. Howarth, R. Marino, L. Martinelli, E. B. Rastetter and J. I. Sprent. 2002. Towards an ecological understanding of biological nitrogen fixation. Biogeochemistry 57-58:1-45.

Wallander, H., K. Arnebrant, F. Ostrand, and O. Karen. 1997. Uptake of ${ }^{15} \mathrm{~N}-$ labelled alanine, ammonium and nitrate in Pinus sylvestris L. ectomycorrhiza growing in forest soil treated with nitrogen, sulphur or lime. Plant and Soil 195: 329-338.

Weaver, P. L., and P. G. Murphy. 1990. Forest structure and productivity in Puerto-Rico's luquillo mountains. Biotropica 22: 69-82.

Zogg, G. P., D. R. Zak, K. S. Pregitzer and A. J. Burton. 2000. Microbial immobilization and the retention of anthropogenic nitrate in a northern hardwood forest. Ecology 81:1858-1866. 
Table 1. Background soil characteristics of each of our three sites. Values are means \pm standard error. Different lowercase letters within a row represent statistically significant $(P<0.05)$ differences among plots.

\begin{tabular}{lccc}
\multicolumn{1}{c}{ Site } & $\begin{array}{c}\text { Tropical } \\
\text { Montane Forest } \\
\mathbf{2}\end{array}$ & $\begin{array}{c}\text { Tropical } \\
\text { Montane Forest }\end{array}$ & $\begin{array}{c}\text { Tropical Montane } \\
\text { Forest } \\
\text { Icacos }\end{array}$ \\
\hline Topographic Position & Windward slope & Windward slope & Leeward slope \\
Bulk Density $\left(\mathrm{g} \mathrm{cm}^{-3}\right)$ & $0.50 \pm 0.033$ & $0.48 \pm 0.034$ & $0.52 \pm 0.046$ \\
\% Soil Moisture & $46.7^{\mathrm{a}} \pm 2.2$ & $52.7^{\mathrm{b}} \pm 1.0$ & $49.2^{\mathrm{ab}} \pm 1.4$ \\
Soil \%N & $0.28^{\mathrm{a}} \pm 0.02$ & $0.38^{\mathrm{b}} \pm 0.02$ & $0.27^{\mathrm{a}} \pm 0.01$ \\
Soil \%C & $5.66^{\mathrm{a}} \pm 0.51$ & $9.21^{\mathrm{b}} \pm 0.57$ & $5.29^{\mathrm{a}} \pm 0.32$ \\
Soil C:N & $20.01^{\mathrm{a}} \pm 0.18$ & $24.50^{\mathrm{b}} \pm 0.58$ & $19.64^{\mathrm{a}} \pm 0.63$ \\
Total Fe oxides* $(\mu \mathrm{gg}$ g-1) & & $21.7 \pm 6.2$ &
\end{tabular}

* Data from E. Dubinsky (personal communication) 
Table 2. Soil N cycling processes measured at each site at 24 hours. Values are means \pm standard error. No standard error was estimated for gross $\mathrm{N}$ cycling rates and mean residence times as data were generated at the plot level. Different lower case letters indicate statistically significant differences among plots.

\begin{tabular}{|c|c|c|c|}
\hline Site & $\begin{array}{c}\text { Tropical } \\
\text { Montane } \\
\text { Forest } 2 \\
\end{array}$ & $\begin{array}{c}\text { Tropical } \\
\text { Montane } \\
\text { Forest } 4 \\
\end{array}$ & $\begin{array}{c}\text { Tropical } \\
\text { Montane } \\
\text { Forest Icacos } \\
\end{array}$ \\
\hline $\begin{array}{l}\text { Gross mineralization } \\
\left(\mu \mathrm{g} \mathrm{g}^{-1} \mathrm{~d}^{-1}\right)\end{array}$ & 1.07 & 3.52 & 1.39 \\
\hline $\begin{array}{l}\text { Gross nitrification } \\
\left(\mu \mathrm{g} \mathrm{g}^{-1} \mathrm{~d}^{-1}\right)\end{array}$ & 2.26 & 1.15 & 0.62 \\
\hline $\begin{array}{l}\text { Gross } \mathrm{NH}_{4}^{+} \text {consumption } \\
\left(\mu \mathrm{g} \mathrm{g}^{-1} \mathrm{~d}^{-1}\right)\end{array}$ & 2.63 & 11.05 & 3.08 \\
\hline $\begin{array}{l}\text { Gross } \mathrm{NO}_{3}^{-} \text {consumption } \\
\left(\mu \mathrm{g} \mathrm{g}^{-1} \mathrm{~d}^{-1}\right)\end{array}$ & 3.19 & 1.06 & 1.34 \\
\hline Mean Residence Time (d): $\mathrm{NH}_{4}{ }^{+}$ & 1.07 & 0.99 & 0.95 \\
\hline Mean Residence Time (d): $\mathrm{NO}_{3}^{-}$ & 0.71 & 0.43 & 0.98 \\
\hline DNRA $\left(\mu \mathrm{g} \mathrm{g}^{-1} \mathrm{~d}^{-1}\right)$ & 0.12 & 1.27 & 0.03 \\
\hline $\begin{array}{l}{ }^{15} \mathrm{~N}_{2} \mathrm{O} \text { Flux }\left(\mathrm{ng} \mathrm{g}^{-1} \mathrm{~d}^{-1}\right) \text { from }{ }^{15} \mathrm{NO}_{3} \\
\text { label }\end{array}$ & $1.93 \pm 1.27$ & $0.012 \pm 0.012$ & $4.77 \pm 5.61$ \\
\hline $\begin{array}{l}\mathrm{N}_{2} \mathrm{O} \text { Flux }\left(\mathrm{ng} \mathrm{g}^{-1} \mathrm{~d}^{-1}\right) \text { from }{ }^{15} \mathrm{NO}_{3} \\
\text { label }\end{array}$ & $15.28 \pm 10.80$ & $0.13 \pm 0.13$ & $26.77 \pm 25.71$ \\
\hline $\begin{array}{l}\text { Plant } \mathrm{N} \text { uptake }\left(\mu \mathrm{g} \mathrm{g}^{-1} \mathrm{~d}^{-1}\right) \text { from } \\
{ }^{15} \mathrm{NH}_{4} \text { label }\end{array}$ & $0.35^{\mathrm{a}} \pm 0.11$ & $0.21^{\mathrm{a}} \pm 0.07$ & $0.79^{b} \pm 0.15$ \\
\hline $\begin{array}{l}\text { Plant } \mathrm{N} \text { uptake }\left(\mu \mathrm{g} \mathrm{g}^{-1} \mathrm{~d}^{-1}\right) \text { from } \\
{ }^{15} \mathrm{NO}_{3} \text { label }\end{array}$ & $0.09 \pm 0.01$ & $0.09 \pm 0.04$ & $0.14 \pm 0.12$ \\
\hline $\begin{array}{l}\text { Microbial } \mathrm{N} \text { uptake }\left(\mu \mathrm{g} \mathrm{g}^{-1} \mathrm{~d}^{-1}\right) \\
\text { from }{ }^{15} \mathrm{NH}_{4} \text { label }\end{array}$ & $-0.039 \pm 0.21$ & $0.46 \pm 0.86$ & $-0.13 \pm 0.55$ \\
\hline $\begin{array}{l}\text { Microbial N uptake }\left(\mu \mathrm{g} \mathrm{g}^{-1} \mathrm{~d}^{-1}\right) \\
\text { from }{ }^{15} \mathrm{NO}_{3} \text { label }\end{array}$ & $0.13 \pm 0.11$ & $0.37 \pm 0.73$ & $-0.20 \pm 0.15$ \\
\hline
\end{tabular}




\section{Figure Legends}

Figure 1. Plant and microbial processes in a wet tropical forest soil during the first 24 hours following ${ }^{15} \mathrm{~N}$ addition. The value included for $\mathrm{NO}_{3}{ }^{-}$leaching was measured at the 7-day sampling point. Values are means $\left(\mu \mathrm{g} \mathrm{g}^{-1} \mathrm{~d}^{-1}\right) \pm 1$ standard error.

Figure 2. Ammonium (solid bars) and $\mathrm{NO}_{3}{ }^{-}$(hatched bars) uptake by microbial biomass and roots over $24 \mathrm{~h}$ following ${ }^{15} \mathrm{~N}$ addition. Error bars represent standard errors.

Figure 3. Principal-component analysis of soil bacterial Terminal Restriction Length Polymorphism (T-RFLP) fragment patterns from three plots in upland humid tropical soils, Puerto Rico. Replicate samples are indicated by symbols/colors, and axes are scaled to percent variance explained. 
Figure 1.

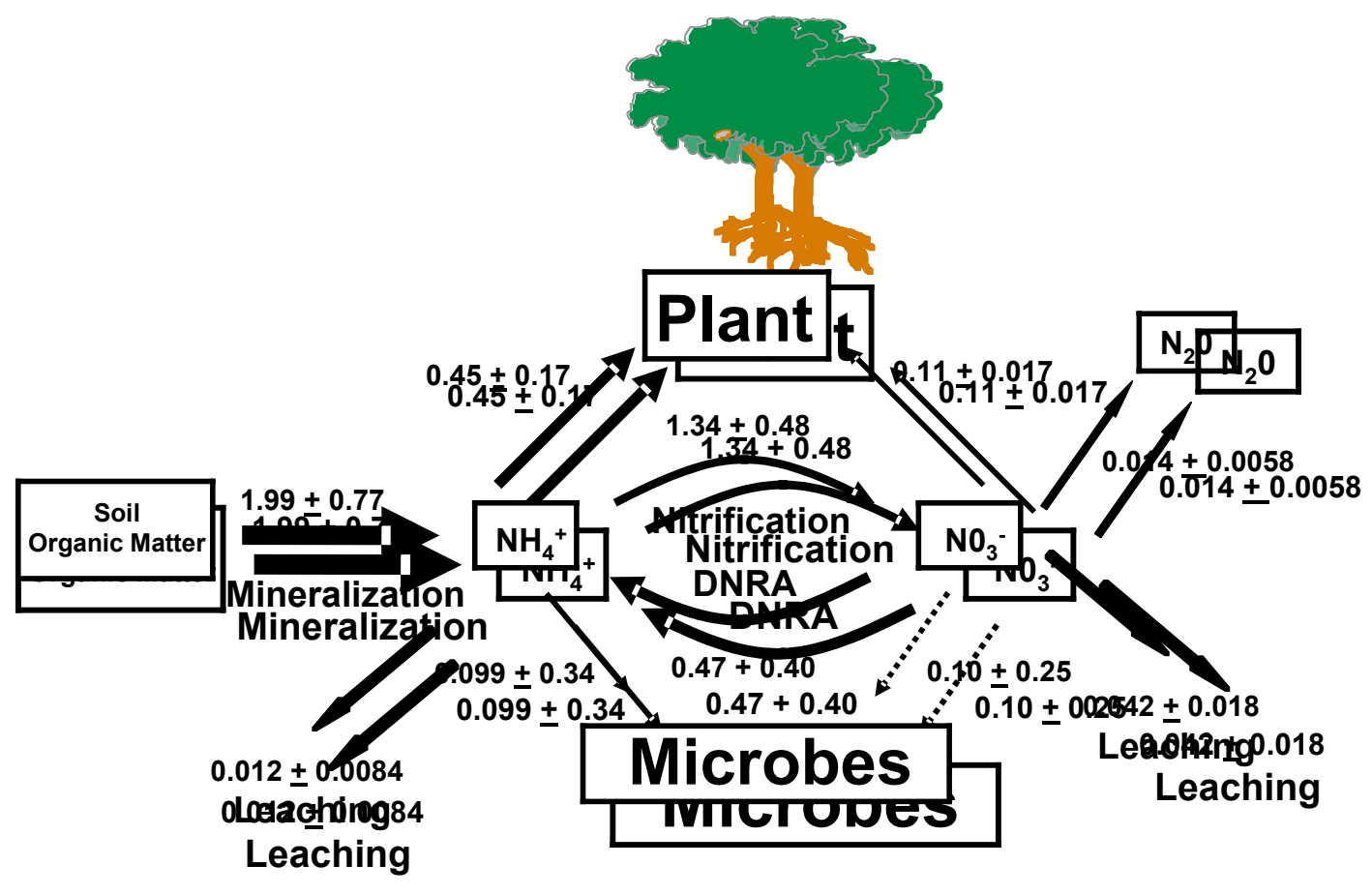


Figure 2.

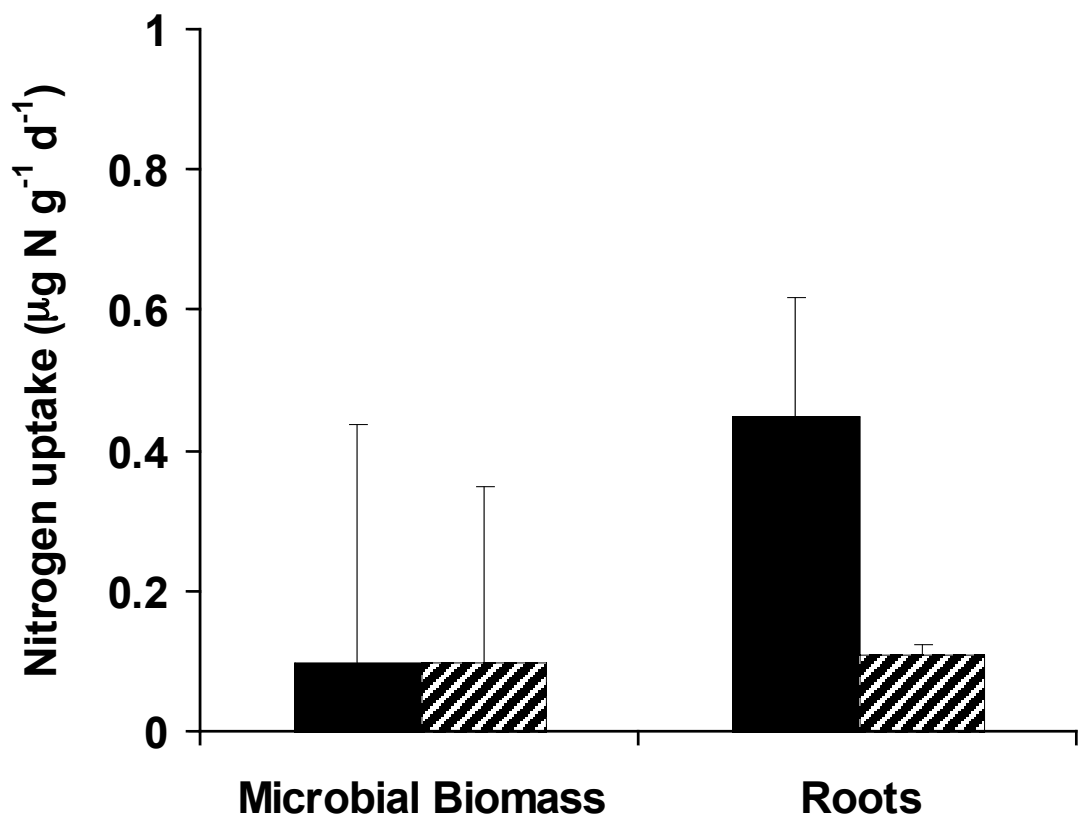

37 
Figure 3.

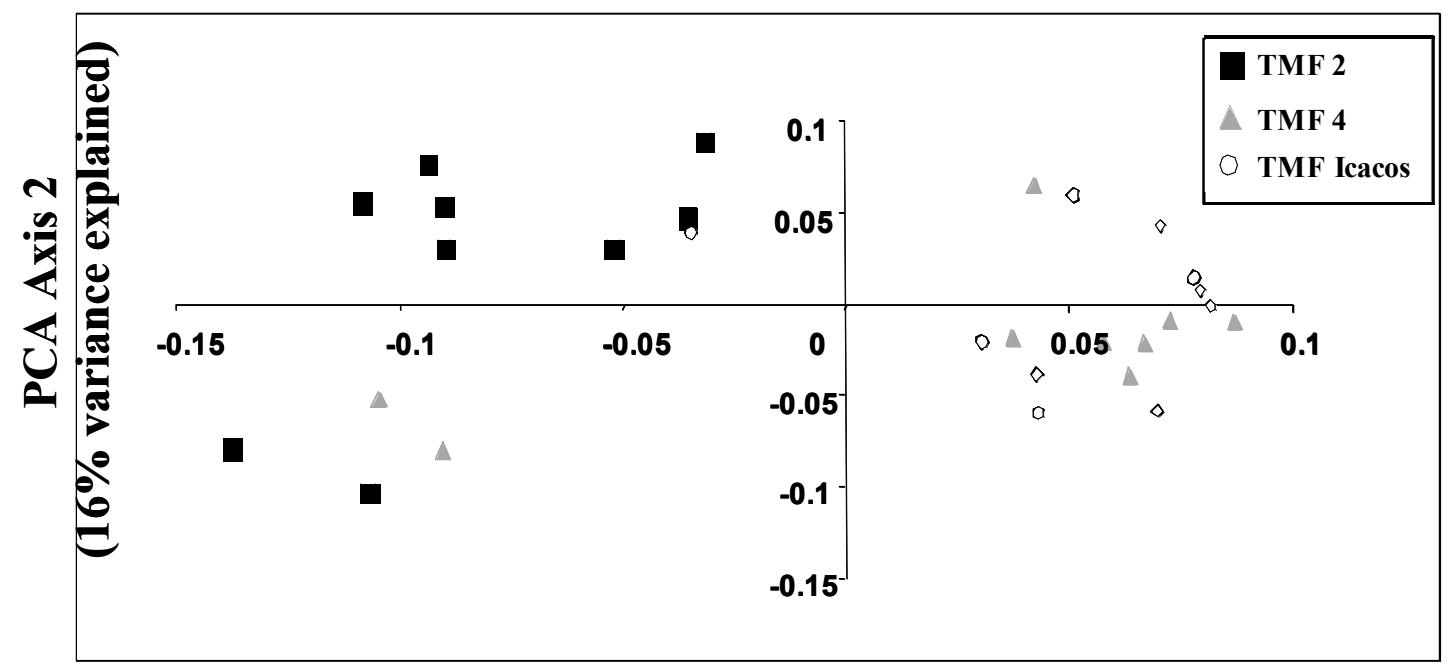

PCA Axis 1 (34\% variance explained) 